\title{
A Política Governamental e os Conglomerados Financeiros
}

\author{
ARNOLD WALD \\ Advogado; professor universitário \\ (UEG); colaborador da RSP desde 1949
}

quiriu Não há dúvida de que, nos últimos vinte anos, o crédito ad. mulu no Brasil uma grande complexidade, multiplicando as fórmulas de financiamento e oferecendo um grande número de alternativas. No fim da II Guerra Mundial, ou seja, em 1945, as formas de crédito em nosso País ainda se limitavam, no fundo, a três : o crédito pessoal baseado na promissória, o crédito comercial com o desconto de duplicatas e o crédito hipotecário. Hoje basta entrar num banco para sentir a revolução ocorrida.

Os próprios títulos se multiplicaram. Fala-se hoje na cédula pignoratícia, na cédula hipotecária, na promissória rural, na duplicata de serviços, na duplicata fiscal, nas letras imobilárias, nas letras hipotecárias etc. Houve, assim, incontestável especialização e sofisticacãa do crédito. Faixas novas surgiram como o em. préstimo para fins habitacionais, com uma série de subcategorias, cada uma delas obedecendo a princípios próprios. O mesmo se poderia dizer das operações de crédito indústrial realizadas pelo BNDE e pelos seus agentes financeiros.

As operações internacionais, com o repasse de emprésti. mos estrangeiros em moeda pesada, autorizado pela legislação atual, os diversos tipos de financiamentos realizados pelos bancos de investimentos, a mobilização do crédito ao consumidor são tan. tas outras inovações que citamos, apenas, a título de exemplo.

As emissões de debêntures, que voltaram a se afirmar depois de longa ausência no mercado brasileiro, os títulos públicos, inclusive obrigações reajustáveis e letras do Tesouro e os títulos estaduais com correção monetária, completam o quadro altamen. te diversificado das estruturas creditícias brasileiras. 
Antigamente, limitava-se o banqueiro a receber depósitos à vista ou a prazo fixo e a emprestar dinheiro descontando duplica. tas e recebendo promissórias. Atualmente, o banco deixou de ser apenas um estabelecimento único - é um complexo de instituições financeiras integradas abrangendo, normalmente, além de um banco comercial, um banco de investimento, uma financeira, uma corretora de valores e uma distribuidora, uma sociedade de crédito imobiliário, uma empresa de "leasing" um ou vários fundos de investimento e até, algumas vezes, uma empresa de turismo, uma sociedade de processamento de dados e uma companhia de seguros. O Banco recebe imposto de renda e depósitos decorrentes da legislação fiscal sobre investimento, faz contratos de investimento mensal, paga as nossas contas, fornece carta de crédito, recebe títulos em custódia ou para serem administrados, tem um serviço de emergência para permitir depósitos e, eventualmente, pagamento de cheques à noite, aos domingos e feriados. Já se conhece a agência bancária "drive in" na qual se recebe o cheque sem sair do automóvel. O cheque já pago, devolvido ao emitente, constitui a melhor prova do pagamento que fizemos. Uma série de serviços são assim prestados pelas instituições financeiras, que abandonaram a posição tradicional de bancos de depósito, para se tornarem verdadeiros bancos de negócios. Todos os banqueiros sabem que há uma única orientação que se lhes impõe : o movimento. Movimento significa, no caso, o aumento da prestação dos serviços, o melhor atendimento, a maior eficácia em todas as formas de operações.

Já se afirmou ser a nossa época a dos "superbancos" que constituem verdadeiros conglomerados financeiros (financial conglomerados), caracterizados por uma reestruturação que obedeceu aos dois princípios básicos da concentração e da expansão. Se, no passado, havia a possibilidade de distinguir entre o banco de depósito e o banco de negócios ou a sociedade financeira e se podiam subsistir, até os meados do presente século, os pequenos e médios bancos, a nossa época exige a apresentação de um ser. viço financeiro integral e de grandes dimensões. As macro-empresas modernas, às sociedades multinacionais da segunda meta: de do nosso século devem corresponder grandes bancos que pos. sam atendê-las em todos os seus interesses, o que implica na necessidade de fundir ou incorporar os bancos menores, criando-se novas organizações gigantescas que passam a dominar o mercado financeiro nacional e internacional.

Na realidade, numa economia em expansão, o setor bancário se desenvolve mais rapidamente que a economia no seu conjunto. Tal fato se explica pelas necessidades da industrialização, 
que exige maior divisão do trabalho e capitais sempre crescentes para o atendimento dos novos investimentos. Assim, o setor bancário passa a ultrapassar, na sua evolução, a progressão do produto bruto nacional. E a expansão dos bancos passa a ser o fruto necessário e lógico do desenvolvimento geral.

Tanto no Japão como na Alemanha, nos Estados Unidos e no próprio Brasil, a transformação sofrida pelos bancos nos últimos anos é impressionante. No Japão os seus recursos próprios aumentaram dez vezes em quinze anos. Na Alemanha, no mesmo período, cresceram $700 \%$.

Além da concentração, da expansão e da internacionaliza. ção, verificamos que o movimento bancário se faz no sentido da diversificação, ou seja, com a finalidade de constituir um conjunto que funcione como um verdadeiro supermercado financeiro integrado ou "department store banking", em que o cliente possa ser atendido em todas as suas operações, por mais distintas e complexas que possam ser, encontrando no banco uma base de apoio com a possibilidade de fornecer-lhe não somente dinheiro, mas informações e idéias válidas.

A concentração crescente realizada nos conglomerados fi. nanceiros fez com que o Secretário de Finanças dos Estados Unidos, David Kennedy, alertasse, ainda em 1969, o Presidente Nixon sobre o perigo da transformação da economia norte-americana que em breve se encontraria "perante uma estrutura econômica do. minada por entre cinqüenta e setenta e cinco empresas gigantes. cas que deteriam o controle do poder industrial e financeiro. Ou seriam dominadas pelos "corporate conglomerates" que controla. riam os grandes bancos, ou seriam os grandes bancos que con. trolariam os grandes conglomerados industriais".

A imagem atual do banqueiro é assim tão distinta da exis. tente no século passado quanto a do advogado de empresa con. temporâneo em relação ao seu colega de cinqüenta anos atrás. O banqueiro não é mais o homem ao qual se recorre eventualmente na hipótese de necessidade de crédito ou de financiamento. É ho. je $o$ engenheiro financeiro dos seus clientes, que aponta os rumos do crescimento da empresa, com a plena utilização de todas as capacidades potenciais. Na realidade, é ele o planejador financeiro da vida da empresa que atende com capitais próprios, com re. passe de capitais alheios estrangeiros ou nacionais, com o lança. mento de ações e obrigações no mercado etc. No campo da ex. portação, ele ajuda o cliente na sua prospecção de mercados, nas suas negociaọões no exterior, fornecendo-lhes contatos e ajuda 
nos países compradores e funcionando como uma verdadeira "trading company" graças aos bancos que o representam nos outros países.

$\mathrm{Na}$ realidade, o banqueiro não pode ignorar a política e os problemas sociais, não the cabendo sofrer as aleas da conjuntura econômica, que, ao contrário, deve prever para evitar ou superar as suas dificuldades. É o homem da administração das empresas e das pesquisas de mercado, do "management" e do "marketing" e é, finalmente, o homem amplamente informado que tem os elementos de fato necessários para poder tomar as suas decisões.

A engenharia financeira hoje atribuida ao banqueiro tem sido definida como a técnica de atendimento das necessidades financeiras da empresa em todas suas formas.

Para atender às necessidades da engenharia financeira foram sendo criados, em todos os bancos, departamentos que contam com equipes de analistas, economistas, engenheiros e advogados para levantar, estudar e expurgar as informações e dar soluções aos problemas mais complexos.

$\mathrm{Na}$ realidade, o banqueiro substituiu a intuição que uțilizava, outrora, nos seus negócios, pelo estudo científico dos balanços, pela pesquisa dos mercados e pelo exame da rentabilidade das operações que os clientes pretendem fazer. É pois, um participante ativo na elaboração das decisões dos seus clientes, indus. triais ou comerciantes.

Já se disse que entre o cliente e o banqueiro se cria uma verdadeira colaboração construtiva na qual cada um apresenta os frutos de sua informação e de sua imaginação.

Por outro lado, os banqueiros são, hoje, cada dia mais, os grandes investidores institucionais, seja em nome próprio, seja em nome e por conta dos fundos que estão sob sua gestão, seja ainda por conta de clientes cujos bens e valores administram. Além das participações comerciais, os bancos aconselham e facilitam as fusões das empresas e as suas transformações, abrindo o seu capital, acompanhando a evolução de suas ações na Bolsa e liderando operações de "taxe over", ou seja, de oferta pública de compra de ações, que se têm desenvolvido muito rapidamente nos últimos anos, tanto na Europa como nos Estados Unidos e que recentemente já estão penetrando na vida brasileira. Desempenham finalmente os bancos importante papel nas operações de reestruturação industrial, sendo, pois, incontestavelmente, as instituições financeiras as grandes catalisadoras das transformações econômi. cas do nosso tempo. 